\title{
Sequential Cloud Point Extraction of Trace Elements from Biological Samples and Determination by Inductively Coupled Plasma Mass Spectrometry
}

\author{
Maria Fernanda Giné, ${ }^{*}, a$ Aparecida F. Patreze, ${ }^{a}$ Edson L. Silva, ${ }^{a}$ \\ Jorge E. S. Sarkis ${ }^{b}$ and Maurício H. Kakazu ${ }^{b}$ \\ ${ }^{a}$ Centro de Energia Nuclear na Agricultura CENA-USP, Universidade de São Paulo, \\ Av. Centenário 303, 13400-970 Piracicaba-SP, Brazil \\ ${ }^{b}$ Instituto de Pesquisas Energéticas e Nucleares, IPEN/CNEN, Travessa rua 400, Cidade Universitária, \\ 05508-000 São Paulo-SP, Brazil
}

\begin{abstract}
A extração no ponto nuvem (CPE) foi realizada em duas etapas seqüenciais para a determinação de elementos traço em soro humano, sangue animal e dieta alimentar por espectrometria de massas com fonte de plasma indutivamente acoplado. A primeira CPE foi realizada adicionando dietil-ditiofosfato, Triton ${ }^{\circledR} \mathrm{X}-114$ seguida de aquecimento a $40{ }^{\circ} \mathrm{C}$, centrifugação e esfriamento a $0{ }^{\circ} \mathrm{C}$. A fase rica em surfactante foi separada para determinar $\mathrm{Cd}, \mathrm{Pb}$ e $\mathrm{Cu}$ pela técnica de quantificação por diluição isotópica. As medidas das razões isotópicas foram caracterizadas por $\mathrm{RSD}<0.7 \%$. O pH da solução empobrecida em surfactantante foi ajustado entre 4 e 5 antes da adição de 4-(2-pirilidazo)resorcinol, Triton ${ }^{\circledast}$ X-114 e seguiram-se os procedimentos para atingir o ponto nuvem. Na segunda fase rica em surfactante extraída foram quantificados Co e Ni pelo método de adições de padrão com RSD < 2\%. Recuperações entre 85 a $96 \%$ foram obtidas para todos os elementos. A exatidão foi aferida pela análise de materiais de referência com valores recomendados e certificados.
\end{abstract}

A two-step sequential cloud point extraction (CPE) of trace elements from small sample volumes of human serum, animal blood, and food diet is proposed to gain analytical information in the analysis by inductively coupled plasma mass spectrometry. The first CPE was attained by adding $O, O$-diethyldithiophosphate, the non ionic surfactant Triton ${ }^{\circledR} \mathrm{X}-114$ followed by heating at $40{ }^{\circ} \mathrm{C}$, centrifugation and cooling at $0{ }^{\circ} \mathrm{C}$. The resulting surfactant-rich phase was separated to determine $\mathrm{Cd}, \mathrm{Pb}$ and $\mathrm{Cu}$ by isotope dilution. Isotope ratio measurements presented $\mathrm{RSD}<0.7 \%$. The residual surfactant-poor phase solution had the $\mathrm{pH}$ adjusted in the range 4 to 5 before the chelating reagent, 4-(2-pyridylazo) resorcinol plus surfactant Triton ${ }^{\circledR} \mathrm{X}-114$ were added followed by the sequence to attain the CPE. Co and Ni were quantified in the second extracted surfactantrich phases by standard additions method with RSD $<2 \%$. Recoveries from 85 to $96 \%$ were obtained for all elements. Analyzing reference materials with certified and recommended values assessed accuracy.

Keywords: sequential cloud point extraction, CPE, inductively coupled plasma mass spectrometry, isotope dilution, biological samples, trace elements

\section{Introduction}

Surfactant mediated phase separation constitutes the basis for the approach known as cloud point extraction ${ }^{1}$ which is a liquid-liquid extraction alternative to that of organic solvents. The main parameter to attain a surfactant monomer agglomeration in a micelle-rich phase is the

*e-mail: mfgine@cena.usp.br surfactant concentration at the cloud point temperature. The temperature-concentration phase diagram is specific for each surfactant. ${ }^{2}$ The effect of additives such as salts and other surfactants also has to be considered. ${ }^{1,3}$ The first application of cloud point extraction for analytical purposes described the micelle aggregation of hydrophobic anionic metal complexes. ${ }^{2}$ The ability of surfactant micelles to bind organic compounds separated by CPE was applied for pre-concentration of organic 
compounds prior to the separation of species by capillary electrophoresis ${ }^{3}$ and chromatography. ${ }^{4}$ The surfactants octylphenoxy polyethoxyethanol (Triton $\left.{ }^{\circledR} \mathrm{X}-114\right)$ and polyoxyethylene(7.5)nonylphenyl ether (PONPE $\left.{ }^{\circledR} 7.5\right)$ with cloud point temperatures (CPT) below $40{ }^{\circ} \mathrm{C}$ and 20 ${ }^{\circ} \mathrm{C}$, respectively, have been used preferentially for cloud point extraction of soluble metal ions complexes..$^{5}$ Both surfactants are characterized by forming a surfactant-rich phase denser than the aqueous solution which interacts with metallic species, mainly in the chelated form. This facilitates the phase separation by gravity or centrifugation at room temperature. Another advantage of surfactants attaining the critical micelle concentration (CMC) at low temperature is the minimum redissolution of micelles into the bulk aqueous solution occurring during phase separation. ${ }^{1}$ Theoretical aspects and applications of phase separations using aqueous solutions of surfactants have been described..$^{5,6}$

Dialkyl phosphorodithiotic acids and the sodium salt diethyldithiophosphate were ligands proposed for solvent extraction of several metals. ${ }^{7,8}$ Several applications of the complexation with DDTP in acidified solutions and cloud point concentration (CPE) have been described in the literature. $^{9-13}$

The formation of micelles at low temperature using PONPE $^{\circledR} 7.5$ allowed the high-efficiency extraction of $\mathrm{Pb}(\mathrm{II})$ ions from saliva samples without any complexant. ${ }^{14}$ The cloud point extraction of water-soluble metal complexes with 4-(2-pyridylazo) resorcinol (PAR) has been described before. ${ }^{15,16}$ A surfactant media is necessary to dissolve chelating reagents such as 1-(2-thiazolylazo)-2naphtol (TAN), ${ }^{17}$ dithizone ${ }^{18}$ and 1-(2-pyridylazo)2-naphtol (PAN). ${ }^{1}$

Cloud point extraction has been extensively described as a separation and pre-concentration procedure for metals prior to their determination by atomic spectrometric techniques. ${ }^{19}$ Specific applications of CPE with Triton ${ }^{\circledR}$ $\mathrm{X}-114$ to determine traces of Bi-dithizonate in urine and human hair by electrothermal atomic absorption spectrometry (ET AAS) have been reported. ${ }^{18}$ The CPE with DDTP and Triton ${ }^{\circledR} \mathrm{X}-114$ was applied to determine Cd in tobacco and water samples with flame atomic absorption spectrometry (F AAS) detection ${ }^{10}$ and $\mathrm{Cd}, \mathrm{Pb}$ and $\mathrm{Pd}$ in blood by ET AAS. ${ }^{11}$ The same reagents were employed for the simultaneous determination of noble metals in urine by electrothermal vaporization inductively coupled plasma mass spectrometry (ETV-ICP-MS) ${ }^{12}$ and Ag, As, $\mathrm{Au}, \mathrm{Cd}, \mathrm{Cu}, \mathrm{Pb}$ and $\mathrm{Se}$ in water samples using ultrasonic nebulization ICP-MS. ${ }^{13}$ The micellar phases are very viscous, and commonly they require dilution. Methanol or ethanol plus nitric acid have been described to facilitate the introduction of micellar phases into $\mathrm{F}$ AAS, ${ }^{10} \mathrm{ET}$ AAS, ${ }^{11}$ ETV-ICP-MS ${ }^{12}$ and ICP-MS. ${ }^{13}$ Tetrahydrofuran has been used for introduction into ETAAS, ${ }^{18}$ or just water has been applied for dilution. ${ }^{15,20}$ The combination of electrothermal devices using appropriately programmed vaporization temperatures avoided matrix interferences in the atomic spectrometry detection of micellar phases. ${ }^{11,12,18}$ The flow injection of small sample volumes $(100 \mu \mathrm{L})$ by using an ultrasonic nebulizer with a dessolvation unit avoided the main drawbacks of introducing micelles dissolved in methanol into an ICP-MS. Seven trace elements were determined by ICP-MS in the transient signals. ${ }^{13}$ Precision characterized by $\mathrm{RSD} \leq 6 \%$ was reported. To overcome matrix effects the extracted analytes by CPE has been quantified by isotope dilution, ${ }^{20}$ and standard additions. ${ }^{14}$ The application of isotope dilution (ID) is convenient to determine trace elements in problematic samples, especially when recoveries are variable or matrix dependent. Nevertheless, quantification by ID requires precise isotope ratio measurements to avoid error magnification on results. ${ }^{21}$ Typical RSD's from 0.1 to $0.5 \%$ for isotope ratio measurements by quadrupole ICP-MS and from 0.05 to $0.2 \%$ using sector-field mass spectrometers ICPSFMS have been reported. ${ }^{22}$ Corrections for mass bias and detector dead time are required to attain accurate results when applying ID.

In this research, a two-step cloud point extractions are planned that produces two surfactant-rich phases in sequence. The micelle extracts are then subjected to oxidative digestion before analysis to facilitate sample introduction and to improve precision on isotope ratio measurements. Quantification by applying either isotope dilution or standard additions is proposed.

\section{Experimental}

\section{Instrumentation}

An inductively coupled plasma mass spectrometer, Element 1 (Finnigan MAT, Bremen, Germany), was used in low-resolution mode with a low-flow $\left(0.6 \mathrm{~mL} \mathrm{~min}^{-1}\right)$ concentric nebulizer (Meinhard, Santa Ana, CA, USA) and a Scott-type spray chamber cooled to $10^{\circ} \mathrm{C}$. The ICPMS operating conditions are summarized in Table 1. The medium and high resolution modes were not practiced for presenting worsen sensitivity and precision. ${ }^{23}$ Samples were digested in a microwave oven (Ethos 1600, Milestone, Italy) installed in a class-100 clean room. A heating block (Tecnal, Piracicaba, Brazil) and a centrifuge (Cientec model 55, Piracicaba, Brazil) were used to accelerate the phase separation. Conical Pyrex centrifuge tubes $(15 \mathrm{~mL})$ 
(Corning, New York, USA) were used. Spikes were applied from solutions at $20^{\circ} \mathrm{C}$ by using a $20.0 \pm 0.04$ to $200.0 \pm$ $0.03 \mu \mathrm{L}$ micropipette (model NPX-200, Nichipet EX, Tokio, Japan).

Table 1. ICP-MS operating conditions

\begin{tabular}{ll}
\hline Cool gas flow rate & $16 \mathrm{~L} \mathrm{~min}^{-1}$ \\
Auxiliary gas flow rate & $0.9 \mathrm{~L} \mathrm{~min}^{-1}$ \\
Sample gas & $1 \mathrm{~mL} \mathrm{~min} \mathrm{~min}^{-1}$ \\
RF power & $1300 \mathrm{~W}$ \\
Sample Flow rate & $0.6 \mathrm{~mL} \mathrm{~min} .^{-1}$ \\
Measurements per peak & 30 \\
Sample time & $0.010 \mathrm{~s}$ \\
Segment duration & $0.150 \mathrm{~s}$ \\
Mass Window & 50 \\
Detection mode & Pulse Counting \\
Spray chamber & Scott type \\
\hline
\end{tabular}

\section{Materials and solutions}

Purified water $(18.2 \mathrm{M} \Omega \mathrm{cm})$ was produced by a Milli-Q system (Millipore Co., Bedford, MA, USA); sub-boiling distilled $\mathrm{HNO}_{3}$ and $\mathrm{HCl}$ acids (Merck, Darmstadt, Germany) and $\mathrm{H}_{2} \mathrm{O}_{2} 30 \%(\mathrm{~m} / \mathrm{v})$ (Suprapur Merck), were used throughout. A quality control standard QCS-21 prepared by High Purity Standards (Charleston, NC, USA) containing 21 elements was used in preliminary tests. Reference standards were prepared from stock solutions of $\mathrm{Cd}, \mathrm{Cu}, \mathrm{Pb}, \mathrm{Co}$ and $\mathrm{Ni}\left(1,000.0 \mathrm{mg} \mathrm{L}^{-1}\right)$ (SPEX, Edison, NJ, USA). Spikes of Co and Ni were obtained from a $1.00 \mathrm{mg} \mathrm{L}^{-1}$ solution. Isotopic spikes were performed from $1.00 \mathrm{mg} \mathrm{L}^{-1}$ solutions enriched in ${ }^{112} \mathrm{Cd}(97.02$ at. \%), ${ }^{65} \mathrm{Cu}\left(99.68\right.$ at. \%) and ${ }^{206} \mathrm{~Pb}(99.74$ at. \%) ( $\mathrm{CIL}$ Cambridge Isotope Laboratories, Andover, MA, USA).
A $0.100 \mathrm{mg} \mathrm{L}^{-1}$ solution of the NIST SRM 982 certified for $\mathrm{Pb}$ isotopic composition was prepared. Acetate buffer solution $\mathrm{pH} 4.5$ was used (Merck). A solution of $10 \% \mathrm{~m} / \mathrm{v}$ DDTP (Sigma, St Louis, MO, USA) in water, (purified as described elsewhere ${ }^{13}$ ) and another containing $10 \mathrm{mmol} \mathrm{L}^{-1}$ PAR (Merck, for synthesis) were used. A $10 \% \mathrm{~m} / \mathrm{v}$ stock solution of Triton ${ }^{\circledast} \mathrm{X}-114\left[4-\left(\mathrm{C}_{8} \mathrm{H}_{17}\right) \mathrm{C}_{6} \mathrm{H}_{4}\left(\mathrm{OCH}_{2} \mathrm{CH}_{2}\right)_{\mathrm{n}} \mathrm{OH}\right]$ (Sigma) surfactant was employed.

\section{Samples and sample preparation}

Certified reference materials including IRMM Human Serum IMEP-17 (Institute for Reference Materials and Measurements) and HPS Mixed Food Diet (High Purity Standards) were analyzed. Blood samples $(0.1 \mathrm{~mL})$ collected from rats contaminated with $\mathrm{Cd}$ were analyzed.

Samples solutions in triplicate received the spiked amounts presented in Table 2 calculated for each sample by the reverse isotope dilution equation. Standards containing 0.5 and $1.0 \mathrm{mg} \mathrm{L}^{-1}$ of $\mathrm{Co}$ and $\mathrm{Ni}$ were used for spiking the samples to perform the standard additions method. The samples and blanks received $3 \mathrm{~mL}$ of nitric acid and $2 \mathrm{~mL}$ of $\mathrm{H}_{2} \mathrm{O}_{2}$ in sequence before digestion in microwave oven in closed PTFE vessels. Three heating steps of 2, 4, and $10 \mathrm{~min}$ at temperatures of $60{ }^{\circ} \mathrm{C}, 85^{\circ} \mathrm{C}$ and $120^{\circ} \mathrm{C}$, respectively were used.

Preliminary experiments of cloud point extraction using DDTP and PAR

The application of cloud point extraction to a $200 \mu \mathrm{g} \mathrm{L}^{-1}$ of QCS-21 in $0.1 \mathrm{~mol} \mathrm{~L}^{-1} \mathrm{HCl}$ solution was performed. The digested micelles were analyzed by ICP-MS in

Table 2. Spiked amounts and experimental isotope ratios and precision $(\mathrm{n}=3)$

\begin{tabular}{|c|c|c|c|c|}
\hline Samples & Estimated mass (ng) & Spiked mass (ng) & Measured Ratio & $\%$ RSD \\
\hline \multicolumn{5}{|c|}{ Mixed Food Diet HPS } \\
\hline${ }^{112} \mathrm{Cd} /{ }^{114} \mathrm{Cd}$ & 60 & $80.0 \pm 0.3$ & 10.5 & 0.41 \\
\hline${ }^{65} \mathrm{Cu} /{ }^{63} \mathrm{Cu}$ & 400 & $150.0 \pm 0.2$ & 1.04 & 0.14 \\
\hline \multicolumn{5}{|c|}{ Samples of animal blood } \\
\hline${ }^{112} \mathrm{Cd} /{ }^{114} \mathrm{Cd}$ & 70 & $65.0 \pm 0.2$ & 8.02 & 0.39 \\
\hline${ }^{65} \mathrm{Cu} /{ }^{63} \mathrm{Cu}$ & 20 & $10.0 \pm 0.5$ & 1.05 & 0.48 \\
\hline${ }^{206} \mathrm{~Pb} /{ }^{208} \mathrm{~Pb}$ & 4 & $5.0 \pm 0.5$ & 2.82 & 0.62 \\
\hline \multicolumn{5}{|c|}{ Human Serum } \\
\hline \multicolumn{5}{|c|}{ IRMM-IMEP-17 } \\
\hline${ }^{112} \mathrm{Cd} /{ }^{114} \mathrm{Cd}$ & 300 & $800.0 \pm 0.1$ & 10.05 & 0.46 \\
\hline${ }^{65} \mathrm{Cu} /{ }^{63} \mathrm{Cu}$ & 3,000 & $1,300.0 \pm 0.1$ & 1.05 & 0.11 \\
\hline${ }^{206} \mathrm{~Pb} /{ }^{208} \mathrm{~Pb}$ & 40 & $300.0 \pm 0.2$ & 15.8 & 0.48 \\
\hline
\end{tabular}


semiquantitative mode. The feasibility of promoting CPE for Co by chelating with several pyridine and thiazole azo compounds was reported before. ${ }^{16,17}$ PAR forms anionic $\mathrm{HR}^{-}$water-soluble complexes with $\mathrm{Co}$ and $\mathrm{Ni}$ at $\mathrm{pH}$ from 4.2 to $7 .{ }^{17}$ However, the capability for simultaneous cloud point extractions using PAR was not established before. Experiments were carried out to characterize the CPE of PAR chelates from a $200 \mu \mathrm{g} \mathrm{L}{ }^{-1}$ QCS-21 solution. Different concentrations of PAR mixed with Triton ${ }^{\circledR} \mathrm{X}-114(0.2 \%$ $\mathrm{m} / \mathrm{v}$ ) were tested. The micelle-rich phases were digested and analyzed directly by ICP-MS as well as the residual surfactant-poor phase to determine the percentage of recovery for each element.

\section{Sequential cloud point extraction procedure}

The proposed sequential CPE scheme is presented on the right side diagram shown in Figure 1. The first extraction was performed from spiked, digested samples at $\mathrm{pH}<1$ by adding $0.5 \mathrm{~mL}$ of the $10 \% \mathrm{~m} / \mathrm{v}$ DDTP and $0.1 \mathrm{~mL}$ of the $10 \%$ surfactant Triton ${ }^{\circledR} \mathrm{X}-114$ to attain $0.2 \%$ $\mathrm{m} / \mathrm{v}$ in the final solution.
Tubes containing the solutions were immersed in a thermostatic bath heated at $40{ }^{\circ} \mathrm{C}$ for $15 \mathrm{~min}$. Immediately after heating, the warm solutions exhibiting turbidity were centrifuged at $4800 \mathrm{rpm}$ for $10 \mathrm{~min}$, and finally the flasks were immersed in an ice bath for $5 \mathrm{~min}$. Two phases were clearly observed: a transparent solution and a white or pale yellow depleted residue. Inverting the tubes separated the supernatant solution corresponding to the surfactantpoor phase. The $\mathrm{pH}$ of the surfactant-poor solutions was adjusted to a $\mathrm{pH}$ range of 4 to 5 with acetate buffer. The PAR mixed with Triton ${ }^{\circledR} \mathrm{X}-114$ solution was added as the chelating reagent to perform another cloud point extraction. A second micelle-rich phase was formed just by heating to $40{ }^{\circ} \mathrm{C}$ for $15 \mathrm{~min}$, followed by centrifugation and cooling in an ice bath. The depleted organic phase exhibited an orange color. After separation, the micelle-rich surfaces and the tube walls were washed twice with $0.5 \mathrm{~mL}$ of water to remove external residues. The separated micelles were easily dissolved by adding $500 \mu \mathrm{L}$ of $\mathrm{HNO}_{3}$ plus $200 \mu \mathrm{L}$ of $\mathrm{H}_{2} \mathrm{O}_{2}$ and heated at $120{ }^{\circ} \mathrm{C}$ for $15 \mathrm{~min}$ in a digestion block to obtain a clear final solution. The micelle containing the DDTP complexes was analyzed by isotope dilution without

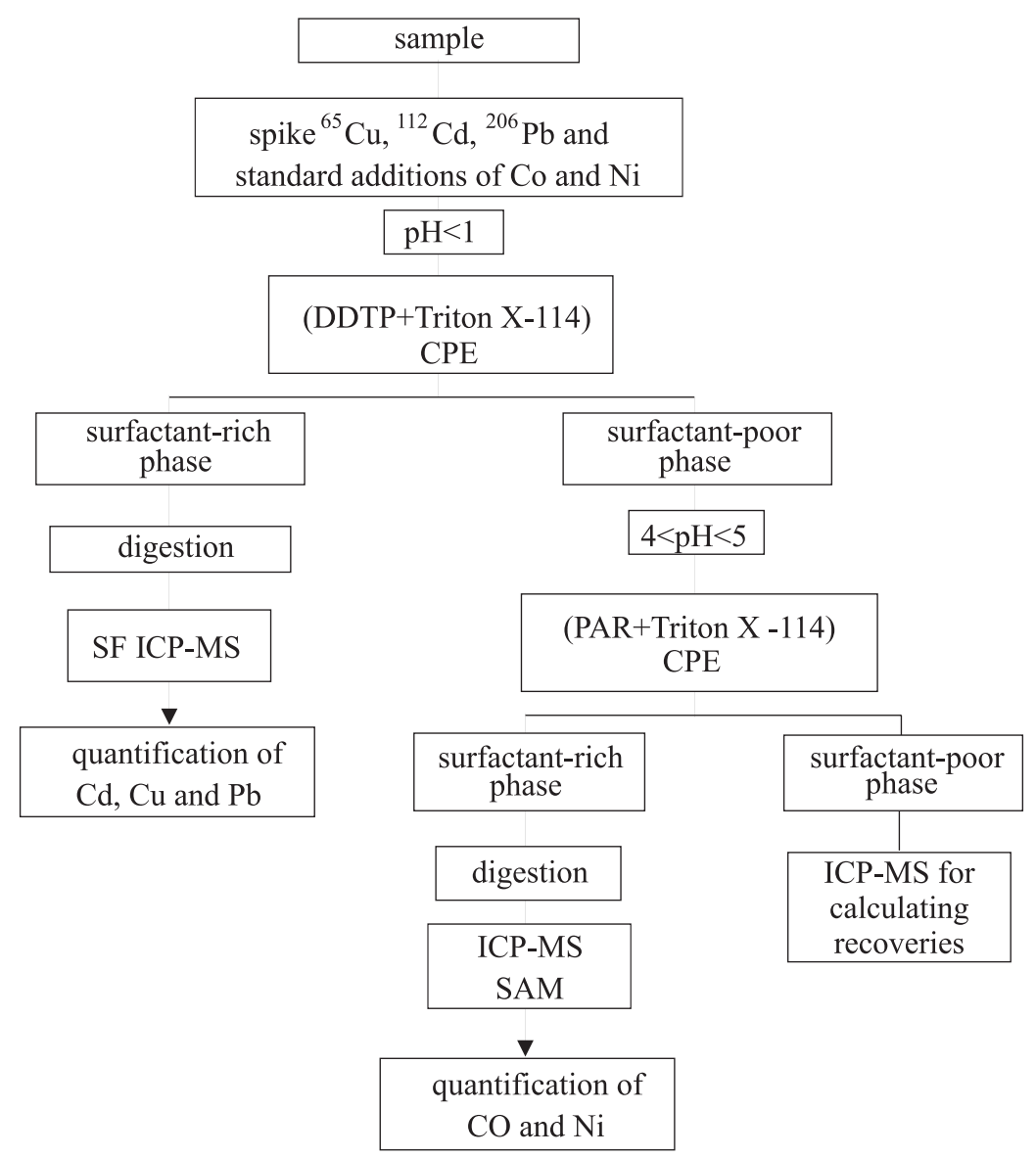

Figure 1. Schematic representation of the sequential cloud point extraction and the quantification procedures. Isotope dilution performed to quantify analytes on the first CPE by measuring isotope ratios (IR) and the standard additions method (SAM) for Co and Ni quantification in the second CPE. 
a volumetric adjustment. After digestion of the second micelle, the volume was made up to $3 \mathrm{~mL}$. The elements in the sample solutions were quantified by standard additions with the addition of $0.0 ; 50.0$ and $100.0 \mu \mathrm{g} \mathrm{L}^{-1} \mathrm{Co}$ and Ni. The surfactant-poor phase separated from the second CPE was also analyzed to calculate recoveries.

\section{Isotope dilution}

In preliminary tests the possibility of quantifying $\mathrm{Cd}$, $\mathrm{Pb}$ and $\mathrm{Cu}$ by isotope dilution in the micelle produced by DDTP and Triton ${ }^{\circledR}$ X-114 was evaluated.

The instrumental conditions were adjusted to measure isotope ratios ${ }^{112} \mathrm{Cd} /{ }^{114} \mathrm{Cd}$ and ${ }^{65} \mathrm{Cu} /{ }^{63} \mathrm{Cu}$ in standard solutions accurately. Due to the $\mathrm{Pb}$ isotopic variability a solution of the Pb isotopic standard NIST SRM 982 was analyzed to determine the instrumental mass bias factor. Detector dead time of $20 \mathrm{~ms}$ was experimentally determined for the $\mathrm{m} / \mathrm{z}$ of interest.

\section{Results and Discussion}

\section{Preliminary results}

Preliminary results of the cloud point extraction of Co and $\mathrm{Ni}$ complexes using PAR are presented in Figure 2. The efficiency of PAR to form chelates with Co could be affected by high concentrations of concomitants, mainly for samples with high concentrations of transition metals in the +2 oxidation state..$^{24} \mathrm{In}$ effect, PAR in acetate medium at $\mathrm{pH}$ 4-6 is also efficient for $\mathrm{Zn}, \mathrm{Cd}, \mathrm{Ni}, \mathrm{Cr}, \mathrm{V}, \mathrm{Ti}, \mathrm{Cu}$ and other metals.

The serial scheme was defined for extracting first several transition elements with DDTP. After separating the micelle, the CPE performed on the surfactant-poor solution in acetate media adding PAR previously mixed with Triton ${ }^{\circledR}$ $\mathrm{X}-114$. Higher stability of PAR in the organized media was observed. An excess of $\left(1 \mathrm{mmol} \mathrm{L}^{-1}\right)$ of PAR was used to overcome effects of concomitants guarantying for $\mathrm{Co}$ and Ni recoveries higher than $95 \%$.

Results of preliminary tests of cloud point extraction performed on standard solutions and blanks demonstrated that more than $90 \%$ of $\mathrm{As}, \mathrm{Cd}, \mathrm{Fe}$ and $\mathrm{Pb}$ and $60 \%$ of $\mathrm{Cu}$ were extracted with DDTP and close to $100 \%$ of $\mathrm{Co}, \mathrm{Ni}$, $\mathrm{V}, \mathrm{Ti}, \mathrm{Cr}$ and $\mathrm{Zn}$ with PAR. No effect from the main matrix constituents in biological samples, such as $\mathrm{Na}, \mathrm{K}, \mathrm{Ca}$ and $\mathrm{Mg}$ was noticed. However, the cloud point extraction of blanks and spiked blanks yielded contamination levels of $0.1 \mathrm{ng} \mathrm{mL}^{-1}$ for $\mathrm{Cd}, \mathrm{Ni}$ and $\mathrm{Co}$ of $3.0 \mathrm{ng} \mathrm{mL}^{-1}$ for $\mathrm{Cu}$ and $\mathrm{Pb}$. Those levels were related to the reagents impurities. To decrease $\mathrm{Cu}$ and $\mathrm{Pb}$ contaminations the purification of
DDTP was provided. Impurities from ${ }^{206} \mathrm{~Pb}$-certificated material (CIL PBLM-3662) of $\mathrm{Cd}<0.05 \%$ and $\mathrm{Cu}<0.01 \%$ becomes important for isotope dilution quantification.

Preliminary tests of sequential cloud point extraction performed in $3 \mathrm{~mL}$ of biological samples allowed estimating the analytes concentration in the residual solution of both micelles.

\section{Quantitative results}

The spiked samples were submitted to the sequential CPE scheme represented in Figure 1. The mole fraction ratio $^{25}$ was used for calculating the spikes. The simplest case was for ${ }^{65} \mathrm{Cu}$ with natural ratio ${ }^{65} \mathrm{Cu} /{ }^{63} \mathrm{Cu}(0.44563)$ and highly enriched spike material with isotope ratio $\mathrm{R}_{\mathrm{s}}>$ 300 , allows projecting a final isotope ratio closed to 1 . In the case of ${ }^{112} \mathrm{Cd}$, the natural isotopic ratio is ${ }^{112} \mathrm{Cd} /{ }^{14} \mathrm{Cd}$ (0.84009) and the $\mathrm{R}_{\mathrm{s}} \sim 100$; then the choice for ratios close to 10 was preferred to obtain highly precise results. For $\mathrm{Cd}$ and $\mathrm{Pb}$ the isotope ratios were variable, increasing when the sample mass was over estimated and a higher mass was spiked. In all situations precise isotope ratio measurements were attained $(\mathrm{RSD}<0.7 \%)$ indicating the effectiveness of micelles digestion procedure. The precision of isotopic ratio measurements on CPE micelles just diluted with nitric acid plus methanol reported elsewhere ${ }^{13}$ was characterized by RSD from 3-8 \%, thus not appropriate for applying isotope dilution quantification. This behavior was attributed to poor aerosol formation and plasma instabilities resulting from the high organic content. The $\mathrm{C}$ content of the digested micelle solutions was less than $0.3 \%$. Uncertainties of isotope ratio measurements on Table 2 were calculated by the counting statistic equation proposed elsewhere ${ }^{25}$ that considers the square root of the sum of the inverse of counts $\mathrm{s}^{-1}$ on both isotopes. Detection limits of $0.10 \mu \mathrm{g} \mathrm{L} \mathrm{L}^{-1}$ for ${ }^{65} \mathrm{Cu} /{ }^{63} \mathrm{Cu}$, $0.06 \mu \mathrm{g} \mathrm{L} \mathrm{L}^{-1}$ for ${ }^{112} \mathrm{Cd} /{ }^{114} \mathrm{Cd}$ and $0.05 \mu \mathrm{g} \mathrm{L}-1$ for ${ }^{206} \mathrm{~Pb} /{ }^{208} \mathrm{~Pb}$

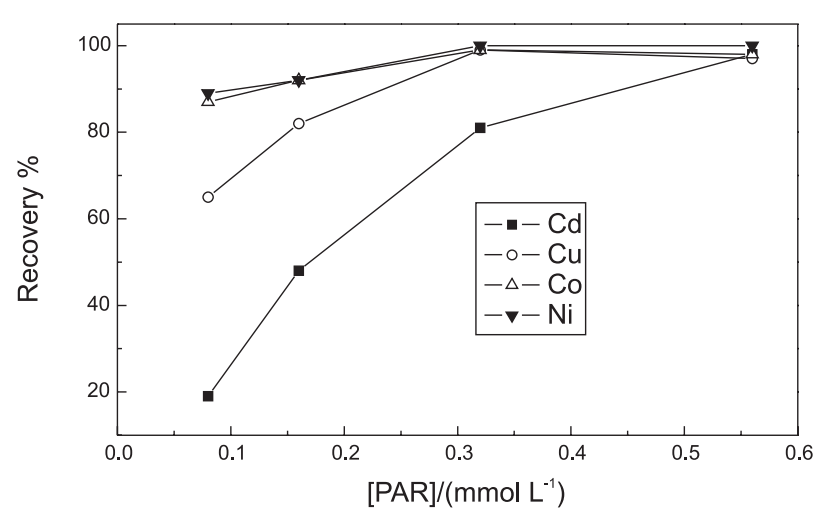

Figure 2. Recoveries attained for different elements in a $200 \mu \mathrm{g} \mathrm{L}^{-1}$ solution chelated with PAR and extracted by Cloud Point Extraction with Triton $^{\circledast}$ X-114 $(0.2 \% \mathrm{~m} / \mathrm{v})$. 
Table 3. Results found in samples, in triplicate, and their reported/certified values

\begin{tabular}{|c|c|c|c|}
\hline Samples & Element & $\begin{array}{c}\text { Found values } \\
\mathrm{mg} \mathrm{L}^{-1}\end{array}$ & $\begin{array}{c}\text { Reported/Certified values } \\
\mathrm{mg} \mathrm{L}^{-1}\end{array}$ \\
\hline \multirow{4}{*}{ Mixed Food Diet (HPS) } & $\mathrm{Cd}$ & $0.012 \pm 0.005$ & 0.008 \\
\hline & $\mathrm{Cu}$ & $0.073 \pm 0.008$ & 0.06 \\
\hline & $\mathrm{Co}$ & $0.0011 \pm 0.0002$ & 0.0008 \\
\hline & $\mathrm{Ni}$ & $0.025 \pm 0.003$ & 0.02 \\
\hline \multirow{4}{*}{ Animal Blood } & $\mathrm{Cd}$ & $0.651 \pm 0.028$ & \\
\hline & $\mathrm{Cu}$ & $0.238 \pm 0.015$ & \\
\hline & $\mathrm{Pb}$ & $0.040 \pm 0.005$ & \\
\hline & $\mathrm{Co}$ & $0.186 \pm 0.009$ & \\
\hline \multirow{4}{*}{ Human Serum (IRMM-IMEP-17) } & & $\mu \mathrm{mol} \mathrm{L}-1$ & $\mu \mathrm{mol} \mathrm{L}-1$ \\
\hline & $\mathrm{Cd}$ & $0.898 \pm 0.030$ & $\mathrm{NC}$ \\
\hline & $\mathrm{Cu}$ & $17.45 \pm 0.50$ & $17.57 \pm 0.1$ \\
\hline & $\mathrm{Pb}$ & $0.058 \pm 0.006$ & $0.08 *$ \\
\hline
\end{tabular}

* average value $\mathrm{NC}$ not certified.

were calculated. ${ }^{26,27}$ The high isotopic enrichment of the spikes led to lowering detection limits of isotope dilution once the spiked blanks presented isotopic ratios closed to the spike solution. ${ }^{26}$ The interferences of $\mathrm{Ar} \mathrm{Na}^{+}$on ${ }^{63} \mathrm{Cu}$ were avoided by washing twice the rich-surfactant surface and the tube walls.

The quantification of $\mathrm{Co}$ and $\mathrm{Ni}$ was performed in micelle-rich produced by CPE using PAR plus Triton ${ }^{\circledR}$ $\mathrm{X}-114$ in the original samples and spiked samples. The LOD for Co and Ni were 0.04 and $0.06 \mu \mathrm{g} \mathrm{L}^{-1}$, respectively. Table 3 lists the average concentrations and uncertainties obtained analyzing three independent sub-samples of different materials. The sample of mixed food diet presented very low concentrations for Co $\left(1.1 \mu \mathrm{g} \mathrm{L}^{-1}\right)$ and $\mathrm{Cd}\left(12 \mu \mathrm{g} \mathrm{L} \mathrm{L}^{-1}\right)$ with precision deteriorated probably by blank corrections. In the case of $\mathrm{Cd}$ uncertainties could also due to mass fraction effects and spiking accuracy. ${ }^{28}$

The sequential CPE procedure generates two surfactantrich extracts containing specific trace elements and a residual solution containing most of the matrix elements.

The analysis of the extracted solutions was performed with no matrix effects since alkaline and alkaline earth elements are not complexed by DDTP or PAR..$^{29}$ The CPE procedure applied to the CRM's, presented recoveries for $\mathrm{Cd}, \mathrm{Pb}, \mathrm{Co}$ and $\mathrm{Ni}$ in the range from 85 to $96 \%$ of the total content.

\section{Conclusions}

The sequential CPE procedure is convenient for trace elements determination in low-volume samples, which elements are separated in small volumes of extracted solutions containing specific analytes. The cloud point extraction performed in biological fluids with Triton ${ }^{\circledR}$
$\mathrm{X}-114$ allowed producing two rich surfactant phases: the first extracting DDTP complexes with $\mathrm{Cd}, \mathrm{Cu}, \mathrm{Pb}$ and the second containing PAR chelates of $\mathrm{Co}$ and $\mathrm{Ni}$. The advantage of the two-step CPE separation procedure over sample mineralization and direct analysis results from the possibility of doubling the volume without diluting the analytes and also performing the analysis with less matrix and interferences effects. The high analytes recoveries reveal the right choice of selective ligands and extraction efficiencies. The subsequent digestion of micelles produced by CPE resulted in highly precise isotope ratio measurements making feasible the quantification by isotope dilution ICP-MS.

\section{Acknowledgments}

The authors thank Conselho Nacional de Desenvolvimento Científico e Tecnológico (CNPq) and Fundação de Amparo à Pesquisa do Estado de São Paulo (FAPESP) for financial support.

\section{References}

1. Watanabe, H.; Tanaka, H.; Talanta 1978, 25, 585.

2. Carabias-Martinez, R.; Rodriguez-Gonzalo, E.; DominguezAlvarez, J.; Hernandez-Mendez, J.; Anal. Chem. 1999, 71, 2468.

3. Watanabe H.; In Solution Behavior of Surfactants; Mitral, K. L.; Fendler, E. J., eds.; Plenum Press: New York, 1982, 1305.

4. Fang, Q.; Yeung, H. W.; Leung, H. W.; Huie, C. W.; J. Chromatogr. A 2000, 904, 47.

5. Quina, F. H.; Hinze, W. L.; Ind. Eng. Chem. Res. 1999, 38, 4150.

6. Hinze, W. L.; Pramauro, E.; Crit. Rev. Anal. Chem. 1993, 24, 133. 
7. Handley, T. H.; Dean, J. A.; Anal. Chem. 1962, 34, 1312.

8. Bode, H.; Arnswald, W.; Fresenius Anal. Chem. 1962, 185, 179.

9. Silva, M. A. M.; Frescura, V. L. A.; Aguilera, F. J. N.; Curtius, A. J.; J. Anal. At. Spectrom. 1998, 13, 1369.

10. Coelho, L. M.; Arruda, M. A. Z.; Spectrochim. Acta, Part B 2005, 60, 743 .

11. Borges, D. L. G.; Veiga, M. A. M. S.; Frescura, V. L. A.; Welz, B.; Curtius, A. J.; J. Anal. At. Spectrom. 2003, 18, 501.

12. Silva, M. A. M.; Frescura, V. L. A.; Curtius, A. J.; Spectrochim. Acta, Part B 2001, 56, 1941.

13. Silva, M. A. M.; Frescura, V. L. A.; Curtius, A. J.; Spectrochim. Acta, Part B 2000, 55, 803.

14. Luconi, M. O.; Silva, M. F.; Olsina, R. A.; Fernandez, L. P.; Talanta 2000, 51, 123.

15. Doroschuk, V. O.; Lelyushok, S. O.; Ishchenko, V. B.; Kulichenko, S. A.; Talanta 2005, 64, 853.

16. Nascentes, C. C.; Arruda, M. A. Z.; Talanta 2003, 61, 759.

17. Chen, J.; Teo, K. C.; Anal. Chim. Acta 2001, 434, 325.

18. Shemirani, F.; Baghdadi, M.; Ramezani, M.; Jamali, M. R.; Anal. Chim. Acta 2005, 534, 163.

19. Bezerra, M. A.; Arruda, M. A. Z.; Ferreira, S. L. C.; Appl. Spectrosc. Rev. 2005, 40, 269.
20. Bellato, A. C. S.; Gervasio, A. P. G.; Giné, M. F.; J. Anal. At. Spectrom. 2005, 20535.

21. Adriaens, A. G.; Kelly, W. R.; Adams, F. C.; Anal. Chem. 1993, 65,660 .

22. Heumann, K. G.; Gallus, S. M.; Radlinger, G.; Vogl, J.; J. Anal. At. Spectrom. 1998, 13, 1001.

23. Yu, L. L.; Vocke, R. D.; Murphy, K. E.; Beck II, C.M.; Fresenius J. Anal. Chem. 2001, 370, 834.

24. Nonova, D.; Evtimova B.; Anal. Chim. Acta 1972, 62, 456.

25. Hayes, J. M.; Schoeller, D. A.; Anal. Chem. 1977, 49, 306.

26. Yu, L. L.; Fasset, J. D.; Guthrie, W. F.; Anal. Chem. 2002, 74, 3887.

27. Saint'Pierre, T. D.; Frescura, V. L. A.; Curtius, A. J.; Talanta 2006, 68, 957.

28. Murphy, K. E.; Long, S. E.; Vocke, R. D.; Anal. Bioanal. Chem. 2007, 387, 2453.

29. Marczenko, Z.; Separation and spectrophotometric determination of elements, $2^{\text {nd }}$ ed., Ellis Horwood: Chichester, 1986.

Received: July 26, 2007

Web Release Date: February 29, 2008

FAPESP helped in meeting the publication costs of this article. 